\title{
The growth of maize in the cool temperate climate of the Netherlands: Effect of grain filling on production of dry matter and on chemical composition and nutritive value
}

\section{B. Deinum and J. Knoppers}

Department of Field Crops and Grassland Husbandry, Agricultural University, Wageningen, Netherlands

Accepted: 8 December 1978

Key-words: maize, dry matter, nutritive value, grain filling

\section{Summary}

A trial in 1975 is described in which the effect of grain filling on productivity and nutritive value of forage maize was studied in three hybrid cultivars. Variation in grain filling was obtained by periodic sampling after silking (end of July) of pollinated (fertile) and unpollinated (sterile) crops.

Production of dry matter of fertile and sterile maize was the same until the end of August, but in September production rate of the sterile crop lagged behind the fertile crop bij about $100 \mathrm{~kg}$ dry matter per ha per day, the difference mainly consisting of non-structural carbohydrate. In the fertile crop, carbohydrate mainly accumulated in the ear as starch, but in the sterile crop it was almost completely stored in the stover as water-soluble carbohydrate. In contrast to the fertile crop, cell-wall production in the sterile stem proceeded through September. Cell-wall digestibility in the stover was not affected by pollination, so because of the smaller yield of non-structural carbohydrate, yield of dry matter and digestible organic matter of the sterile crop were 14 and $17 \%$ less than of the fertile crop at the final sampling. These differences might become greater in the silage.

These data collected in that sunny season of 1975 and from the literature suggest that in bright and warm weather yield of sterile maize will greatly lag behind fertile maize, but in adverse conditions (lower irradiance and temperature, high plant density, unhealthy leaves) this yield lag would be smaller. So grain filling is important for a good production and nutritive value of forage maize in cool regions with little sun but it is less essential than in brighter and warmer climates.

\section{Introduction}

Yield, dry-matter content and ear content are considered essential criteria in 
breeding maize for silage, but there are some doubts about the importance of the latter.

In tropical and subtropical regions with a high light intensity, grain filling occurs almost completely on current photosynthesis (Allison \& Watson, 1966), but in partially defoliated plants and in dense crops photosynthesis seems insufficient for a full supply of dry matter to the grain, so grain filling partially occurs at the expense of non-structural material from the stover (Allison, 1969).

Similarly in the sombre autumn climate in the Netherlands (Becker \& de Haan, 1955; Deinum \& Dirven, 1971) and in Britain (Wilkinson \& Osbourn, 1975) the ear gains weight at the expense of the stover, sometimes to such an extent that in the dreary autumn of 1974 (B. A. ten Hag, 1976, personal communication) grain filling was completely at the expense of the stover. So grain filling may not be an essential criterion in maize for silage, even more so as Bunting (1975) and Allison \& Watson (1966) show that sterile plants can accumulate large amounts of assimilates in the stover.

The question then arises how important grain filling is for yield and quality in our cool temperate climate. More specifically, how does the maize plant grow, how does it distribute its dry matter and how great are the yield losses when the plants grow sterile, especially in regions with low light intensity during grain filling. A trial was set up in 1975 to try to answer these questions in an experiment of which the results are summarized in this paper.

\section{Material and methods}

The experiment was laid out as a completely randomized block design with three cultivars, two treatments (sterile and fertile) in four replicates on a moist sandy soil.

The three hybrids were Anjou 210, an early grain maize, Capella, a medium late silage maize with a rather high ear yield and Onix 95, a medium-late silage maize with somewhat lower ear yield. They were sown at $20 \mathrm{~m}^{-2}$ on 24 April 1975. The soil was fertilized abundantly with chicken manure and fertilizer well before sowing. After emergence, the crop was thinned to about $10 \mathrm{~m}^{-2}$. Row width was $75 \mathrm{~cm}$.

In the sterile treatments, plants were deprived of grain filling by pulling paper bags over the silks and the ear as soon as possible after ear emergence, so preventing pollination. The fertile plants were allowed to pollinate freely.

The plots occupied an area of $12 \mathrm{~m} \times 3 \mathrm{~m}$ each and were subsampled at $2 \mathrm{~m} \times 1.5 \mathrm{~m}$ on 16 July before tasselling, and on 1,15 and 29 September during grain filling. The samples were analysed for number of plants, fresh and dry weight of leaf blade, leaf sheath, stem + tassel, husks + shanks and ear (grain + cob).

Samples were dried at $65^{\circ} \mathrm{C}$ in forced ventilated ovens. After drying, the samples of the four replicates were bulked per plant part and per treatment and analysed for crude protein ( $\mathrm{cp}=\mathrm{N} \times 6.25$ ), ash, crude fibre (cf), water-soluble carbohydrate (wsc), total non-structural carbohydrate (tnc $=$ wsc + starch), cell- 
wall constituents $(\mathrm{cwc})$ and true digestibility in vitro of organic matter. Starch from tnc was hydrolysed with amyloglucosidase and together with the wsc analysed with anthrone. The wsc analysis was done later with ferricyanide. Both are expressed as anhydroglucose $\left(\mathrm{C}_{6} \mathrm{H}_{10} \mathrm{O}_{5}\right)$. Cell-wall constituents and true digestibility in vitro of organic matter were estimated by the method of Van Soest (1977) and Van Soest et al. (1966), respectively, allowing calculation of cell-wall digestibility $\left(D_{\text {cwc }}\right)$. Digestibility in vitro of organic matter $\left(D_{o m}\right)$ is expressed as apparent digestibility of organic matter by subtracting 13 percentage units according to Van Soest et al. (1966).

\section{Results}

The 1975 season was favourable for a good maize crop, with beautiful weather in July, August and September (Table 1). During a dry spell in August drought was prevented by sprinkling $60 \mathrm{~mm}$ of water.

Plant emergence occurred around 10 May, and mid silk around 29 July. The crop grew rather tall to about $2.80 \mathrm{~m}$. Varietal differences were hardly detected in plant development, yield, dry-matter distribution and ripening. They were seldom significant, possibly because of the favourable weather.

At the end of September sterile plants seemed somewhat greener and they were much more resistant to lodging than the fertile plants. Killing frosts did not occur.

\section{Production and distribution of dry matter}

Fig. 1 reveals the course of production and distribution of dry matter in the fertile and sterile plants. Total production of both crops was identical up to the beginning of September with a production rate of about $200 \mathrm{~kg}$ dry matter ha-1 $\mathbf{d}^{-1}$ from 16 July till 1 September. Afterwards production rate of the sterile crop lagged behind the fertile crop by about $100 \mathrm{~kg} \mathrm{ha}^{-1} \mathrm{~d}^{-1}$, the difference mainly consisting of tnc. Final yield reached over $18 \mathrm{t} \mathrm{ha}^{-1}$ in the fertile crop, which is well above average Dutch yield of about $13 \mathrm{tha}^{-1}$.

Dry-matter distribution was strongly influenced by grain filling (Table 2). In the fertile crop about $48 \%$ of the dry matter was accumulated in the ear, whereas it was only $7 \%$ in the sterile crop at the final sampling. Fig. 1 and Table 2 show

Table 1. Weather in 1975 and means over 30 years.

\begin{tabular}{|c|c|c|c|c|c|c|}
\hline \multirow[t]{2}{*}{ Month } & \multicolumn{2}{|c|}{$\begin{array}{l}\text { Solar irradiance } \\
\left(\mathrm{J} \mathrm{cm}^{-2} \mathrm{~d}^{-1}\right)\end{array}$} & \multicolumn{2}{|c|}{$\begin{array}{l}\text { Temperature } \\
\left({ }^{\circ} \mathrm{C}\right)\end{array}$} & \multicolumn{2}{|c|}{$\begin{array}{l}\text { Rainfall } \\
(\mathrm{mm})\end{array}$} \\
\hline & mean & 1975 & mean & 1975 & mean & 1975 \\
\hline May & 1644 & 1710 & 12.4 & 11.0 & 53 & 41 \\
\hline June & 1776 & 2004 & 15.5 & 15.0 & 56 & 86 \\
\hline July & 1583 & 1830 & 17.0 & 17.6 & 85 & 92 \\
\hline August & 1376 & 1812 & 16.8 & 19.5 & 88 & $54(+60)$ \\
\hline September & 1011 & 1089 & 14.3 & 15.1 & 66 & 73 \\
\hline
\end{tabular}



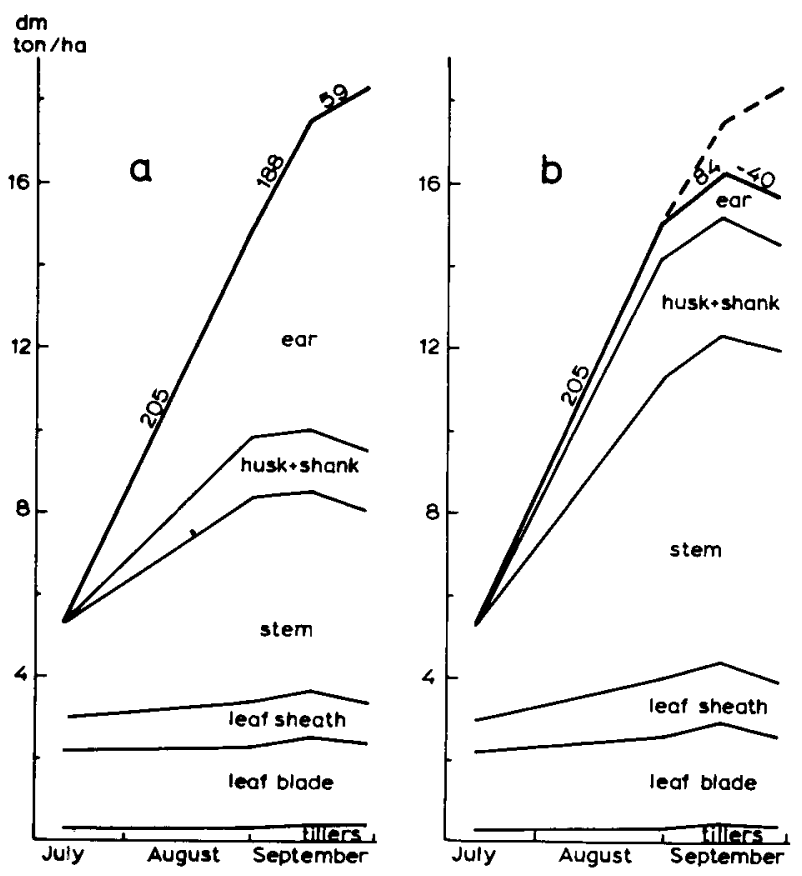

Fig. 1 Course of production and distribution. $\mathrm{a}=$ Fertile and $\mathrm{b}=$ Sterile maize. Data adjusted to 9.5 plants $\mathrm{m}^{-2}$. Average of three hybrids. Numbers along the lines are production rates of dry matter in $\mathrm{kg} \mathrm{ha}^{-1} \mathrm{~d}^{-1}$.

that all vegetative parts of the sterile plants were heavier; apparently they accumulated the dry matter that would normally be translocated to the grain. These data agree well with those of Bunting (1976) from his trials in England in the bad autumn of 1974. Fig. 1 also shows that grain filling in the fertile plants mainly occurred from photosynthesis in the bright and warm conditions of September 1975 and only slightly from redistribution of dry matter from the stover. That is in contrast with Bunting's data (1976) from 1974.

Table 2. Dry matter production and distribution $\left(\mathrm{t} \mathrm{ha}^{-1}\right)$ of the three hybrids on 29 September 1975 .

\begin{tabular}{|c|c|c|c|c|c|c|c|c|}
\hline & \multicolumn{4}{|c|}{ Fertile } & \multicolumn{4}{|l|}{ Sterile } \\
\hline & Anjou & Capella & Onix 95 & 5 mean & Anjou & Capella & Onix 95 & 5 mean \\
\hline Leaf blade & 1.84 & 1.87 & 2.12 & 1.95 & 2.23 & 2.07 & 2.13 & 2.14 \\
\hline Leaf sheath & 1.00 & 1.04 & 1.06 & 1.04 & 1.34 & 1.28 & 1.37 & 1.33 \\
\hline Stem & 5.03 & 4.64 & 4.54 & 4.75 & 8.03 & 7.77 & 8.39 & 8.08 \\
\hline Husk + shank & 1.45 & 1.51 & 1.27 & 1.42 & 2.20 & 3.43 & 2.08 & 2.55 \\
\hline Ear & 7.78 & 9.52 & 9.15 & 8.84 & 1.14 & 1.22 & 1.13 & 1.16 \\
\hline Axillary tiller & 0.41 & 0.48 & 0.23 & 0.37 & 0.40 & 0.49 & 0.32 & 0.41 \\
\hline Total & 17.51 & 19.06 & 18.37 & 18.31 & 15.34 & 16.26 & 15.42 & 15.67 \\
\hline
\end{tabular}


Table 3. Dry-matter content (\%) in stover and ear of sterile and fertile maize on different dates. Average of the three hybrids.

\begin{tabular}{|c|c|c|c|c|c|c|}
\hline \multirow[t]{2}{*}{ Date } & \multicolumn{2}{|l|}{ Stover } & \multicolumn{2}{|l|}{ Ear } & \multicolumn{2}{|c|}{ Whole crop } \\
\hline & sterile & fertile & $\overline{\text { sterile }}$ & fertile & sterile & fertile \\
\hline 16 July & 9.3 & 9.3 & & & 9.3 & 9.3 \\
\hline 1 September & 21.8 & 17.1 & 14.6 & 37.3 & 20.8 & 20.5 \\
\hline 15 September & 24.1 & 18.3 & 17.8 & 46.9 & 22.8 & 24.2 \\
\hline 29 September & 27.7 & 21.4 & 21.0 & 53.7 & 26.2 & 29.7 \\
\hline
\end{tabular}

\section{Content of dry matter}

The data on dry-matter content are presented in Table 3 , which gives only the data on ear, stover and whole crop. Maize is a very moist crop at the end of its vegetative phase, but gets drier towards ripening, most rapidly in the final phase. That agrees with the data of Bunting $(1975,1976)$. In the final phase, dry-matter content increased quickly in the fertile crop, but slower in the sterile maize.

However sterile and fertile plants behaved completely differently in dry-matter content of the various plant parts. The fertile plants showed high contents in the ear, whereas stover was very moist, much moister than in the sterile plants, as found by Bunting (1976). This was true not only for whole stover but for all parts of it, differences being greatest in the stem (16.5 and $24.7 \%$ dry matter in fertile and sterile stem respectively at the final sampling). This high dry-matter content of the stover was completely caused by the great accumulation of cell solubles as will be shown later. Dry-matter content was the same on cell-soluble free basis.

The strange phenomenon occurred in this trial that the seed was almost ripe for grain harvest at the final sampling, whereas the straw was still very wet. The peculiar weather conditions of 1975 may have been responsible. In other years with different weather, moister ears and drier stovers have been found (Wilkinson \& Osbourne, 1975; Bunting, 1976; B. A. ten Hag, 1976, personal communication).

\section{Production of chemical constituents}

Even with the great relative differences in dry-matter distribution between the treatments (fertile/sterile), there were only small differences in production of the various constituents.

Uptake of nitrogen from the soil amounted to about $270 \mathrm{~kg} \mathrm{ha}^{-1}$ resulting in $1690 \mathrm{~kg}$ crude protein $\mathrm{ha}^{-1}$ which was reached on 15 September. Uptake of $\mathbf{N}$ was still about $20 \mathrm{~kg} \mathrm{ha}^{-1}$ during the first 2 weeks of this month. It was the same in fertile and sterile crops resulting in a $\mathrm{N}$ content in the whole crop of 1.50 and $1.66 \%$, respectively, at the final sampling. Nitrate was not accumulated in either crop.

Yield of minerals reached about $840 \mathrm{~kg} \mathrm{ha}^{-1}$ which was already present on 1 September. There was a loss of minerals of $40 \mathrm{~kg} \mathrm{ha}^{-1}$ and of $10 \mathrm{~kg} \mathrm{~N} \mathrm{ha}^{-1}$ 
in the sterile crop during the last 2 weeks of the trial. These losses may have been translocated to the root system, which was still healthy. Leaching from dead and decaying leaves was unlikely to have occurred as it appeared only in the sterile crop with as many dead leaves as the fertile crop.

Production of cwc continued to increase up to the final sampling and reached yields of about $7000 \mathrm{~kg} \mathrm{ha}^{-1}$, corresponding to what Becker \& de Haan (1955) found for crude fibre. In the fertile crop the increase in yield during September originated from cell-wall production in the grain, in the sterile crop from production in the stover.

The residue (other than $\mathrm{cp}$, ash, tnc and cwc) is composed of the fats in the grain and the organic acids in the stover that are formed during the nitrate reduction. This fraction in the stover amounted to about $500 \mathrm{~kg} \mathrm{ha}^{-1}$ which agrees fairly well with the nitrogen uptake of $270 \mathrm{~kg} \mathrm{ha}^{-1}$. The acids were mainly present in the leaf blades and leaf sheats. The other $300-400 \mathrm{~kg} \mathrm{ha}^{-1}$ in the fertile crop corresponds well with the oil in the grain (content in grain $4 \%$; yield of grain $8 \mathrm{tha}^{-1}$ ).

Yield of thc increased similarly in the fertile and sterile crop up to the end of August. It increased well in the fertile crop during September to $7500 \mathrm{~kg} \mathrm{ha}^{-1}$ but the yield increase was about $70 \mathrm{~kg} \mathrm{ha}^{-1} \mathrm{~d}^{-1}$ less in the sterile crop. There are several possible explanations of that lower yield.

- The stover of the sterile plants became saturated with carbohydrate in that sunny year.

- Respiration may have been much greater in the sterile plants rich in wsc as J. Vos (1976, personal communication) has found in wheat straw with a high wsc content just before dying.

- The greater damage to the sterile crop during covering of the ear (broken leaf blades and damaged leaf sheaths that protected the developing ear) eventually reduced photosynthesis in September.

- A greater proportion of the tnc was incorporated in structural material.

- A greater part of the tnc may have been translocated to the root system together with $10 \mathrm{~kg} \mathrm{~N}$ and $40 \mathrm{~kg}$ minerals per ha (Palmer et al., 1973).

So the smaller dry-matter production of the sterile crop was mainly due to the smaller yield of tnc.

\section{Composition of the various morphological components}

Table 4 shows the chemical composition of the different components at the final sampling. The ear was most digestible and the stem least digestible in the fertile plant, as expected. The husks and shanks also showed a good digestibility. Stems and husks + shanks were the greatest accumulators of thc in the stover. All vegetative parts of the sterile plants were richer in cell solubles ( $=100-\mathrm{cwc}$ ) and lower in cwc than the fertile plants, especially the stems as could be inferred from Fig. 1. Bunting's (1975, 1976) and Allison's \& Weinmann's (1970) data suggest the same. No further attention will be paid to the various vegetative parts, and only the whole stover will be considered. 


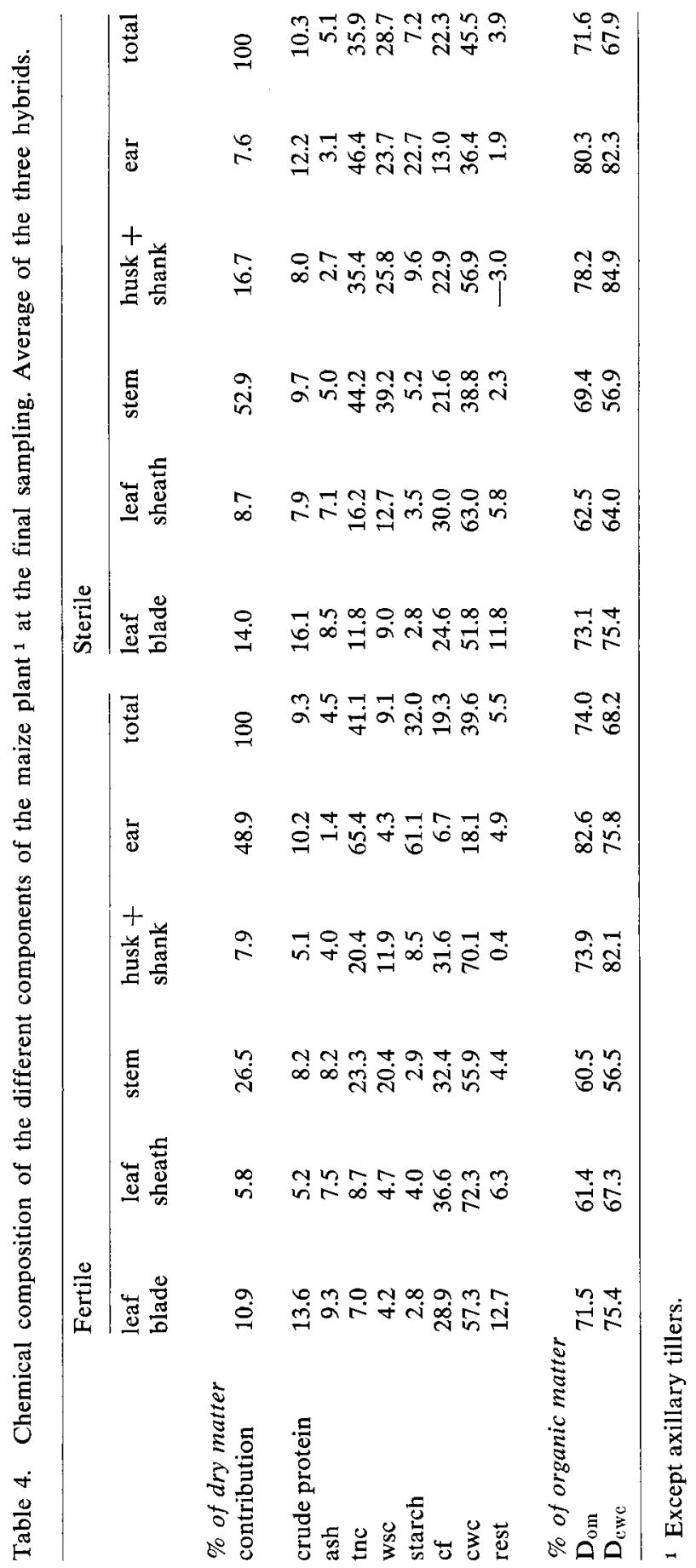


Chemical composition and digestibility

Table 4 also reveals the chemical composition of the fertile and sterile crop at the final sampling. The nitrogen and ash content of the fertile plants were less than of the sterile corresponding with the greater production. Most of the protein and little of the minerals were present in the ear, suggesting a large translocation of protein and a small one for minerals.

The content of tnc was higher in the fertile crop as expected. Only a small proportion of this carbohydrate in the stover was starch in agreement with McAllan \& Phipps (1977). But in the grain, its contribution was very large. Consequently the tnc of the fertile crop was mainly starch but in the sterile crop it was water-soluble. Most of the tnc of the fertile plants was accumulated in the ear and in the sterile plants in the stover. Bunting (1976) found similar contents of wsc in the stover, but higher in the ears in 1974.

The contents of cf and cwc were lowest in whole crop of the fertile plants, mainly because of the higher tnc \%. However in the stover of the sterile plants, contents were very low, because of the great accumulation of tnc.

$\mathrm{D}_{\mathrm{om}}$ of the whole plant was highest in the fertile crop as might be expected from the greater production of the completely digestible tnc. But digestibility of the stover of the sterile plants was extremely good because of the great accumulation of wsc. Finally, $\mathrm{D}_{\text {cwe }}$ was not much effected by grain filling.

Consequently $\mathrm{D}_{\mathrm{om}}$ of the sterile crop was lower than of the fertile crop. Bunting (1976) found otherwise in the bad autumn of 1974, with a small yield increase in September.

\section{Production of cell-wall constituents in the stover}

Because of the smaller yield of tnc in the sterile crop, one might ask whether part of this carbohydrate was metabolized into structural material. Table 5 presents information on this matter, showing, in agreement with Daynard et al. (1969), that in the fertile stalk, yield of cf and cwc did not increase in September, but that in the stems of the sterile crop more cf and cwc were formed in August and September.

Table 5. Yield of crude fibre and cell-wall constituents of the stem of maize on different dates. Average of the three hybrids.

\begin{tabular}{|c|c|c|c|c|c|c|c|c|}
\hline \multirow[t]{2}{*}{ Date } & \multicolumn{4}{|l|}{ Fertile } & \multicolumn{4}{|l|}{ Sterile } \\
\hline & $\begin{array}{l}\text { cf } \\
\left(\mathrm{kg} \mathrm{ha}^{-1}\right)\end{array}$ & $\begin{array}{l}\mathrm{cwc} \\
(\mathrm{kg} \mathrm{ha-1})\end{array}$ & $\begin{array}{l}\text { undigest- } \\
\text { ible cwc } \\
\left(\mathrm{kg} \mathrm{ha}^{-1}\right)\end{array}$ & $\begin{array}{c}\mathrm{D}_{\text {cwe }} \\
(\%)\end{array}$ & $\begin{array}{l}\text { cf } \\
(\mathrm{kg} \mathrm{ha}-1)\end{array}$ & $\begin{array}{l}\mathrm{cwc} \\
(\mathrm{kg} \mathrm{ha}-1)\end{array}$ & $\begin{array}{l}\text { undigest- } \\
\text { ible cwc } \\
(\mathrm{kg} \mathrm{ha-1)}\end{array}$ & $\begin{array}{c}\mathrm{D}_{\mathrm{cwc}} \\
(\%)\end{array}$ \\
\hline 16 July & 690 & 1200 & 380 & 68.3 & 690 & 1200 & 380 & 68.3 \\
\hline 1 September & 1490 & 2610 & 1180 & 54.8 & 1630 & 2950 & 1340 & 54.2 \\
\hline 15 September & 1460 & 2620 & 1140 & 56.6 & 1560 & 2950 & 1240 & 57.9 \\
\hline 29 September & 1530 & 2640 & 1150 & 56.5 & 1750 & 3130 & 1350 & 56.8 \\
\hline
\end{tabular}


Table 6. Chemical composition of ear and stover of Anjou 210 and Capella at the final sampling. Fertile treatment only.

\begin{tabular}{|c|c|c|c|c|c|c|}
\hline & \multicolumn{2}{|l|}{ Stover } & \multicolumn{2}{|l|}{ Ear } & \multicolumn{2}{|l|}{ Total } \\
\hline & Anjou & Capella & Anjou & Capella & Anjou & Capella \\
\hline $\begin{array}{l}\text { Yield } \\
(\mathrm{t} \mathrm{dm} \mathrm{ha-1)}\end{array}$ & 9.6 & 9.6 & 7.8 & 9.5 & 17.5 & 19.1 \\
\hline \multicolumn{7}{|c|}{$\%$ of dry matter } \\
\hline $\mathrm{cp}$ & 9.5 & 7.8 & 9.9 & 10.3 & 9.7 & 9.1 \\
\hline ash & 7.8 & 7.5 & 1.3 & 1.5 & 4.9 & 4.4 \\
\hline $\operatorname{tnc}$ & 21.5 & 16.7 & 65.8 & 63.1 & 41.8 & 40.5 \\
\hline wsc & 16.7 & 12.9 & 4.3 & 4.3 & 11.1 & 8.5 \\
\hline starch & 4.8 & 3.8 & 61.5 & 58.8 & 30.6 & 32.0 \\
\hline cf & 29.7 & 32.7 & 6.8 & 7.3 & 19.2 & 19.7 \\
\hline cwc & 56.9 & 61.9 & 18.4 & 19.6 & 39.4 & 40.2 \\
\hline \multicolumn{7}{|c|}{$\%$ of organic matter } \\
\hline$D_{o m}$ & 67.6 & 63.5 & 82.7 & 82.1 & 74.7 & 73.3 \\
\hline$D_{\text {ewe }}$ & 67.4 & 64.2 & 76.9 & 75.4 & 69.5 & 67.4 \\
\hline
\end{tabular}

Digestibility of these cell walls was the same in both treatments, so part of the completely digestible tnc was transformed into the less digestible structural carbohydrate, which amounted to $500 \mathrm{~kg} \mathrm{ha}^{-1}$. That is a second reason for the lower digestibility of the sterile crop.

\section{Varietal differences in chemical composition}

Three cultivars were used in this experiment of which Anjou 210 was a grain maize and Capella and Onix 95 were forage maize. Table 6 shows the composition of Anjou 210 and Capella; Onix 95 is not mentioned as its chemical composition was almost identical to Capella. The grain maize Anjou 210 produced less ear than Capella and consequently extracted less protein, minerals and tnc from the stover. So its stover was lower in cf and cwc. This accords well with the data of Spiertz (1974) for wheat which yielded better straw when there was less grain.

This and the better $D_{c w c}$ of Anjou 210 results in a better digestibility of the stover and the whole crop. So the cultivar with the smallest ear content had the best $\mathrm{D}_{\mathrm{om}}$ in this trial.

\section{Effect of age on nutritive value}

Fig. 2 presents the changes in nutritive value with time. Protein and ash content declined decreasingly in the fertile crop. The same is true for the content of cwc, which declined rapidly because of the production of tnc. This great production overcompensated the small decline in $\mathrm{D}_{\mathrm{cwc}}$. So $\mathrm{D}_{\mathrm{om}}$ increased with time in this beautiful autumn. Perhaps $\mathrm{D}_{\mathrm{om}}$ declines with age in autumns with cloudy weather when the small production of tnc cannot compensate for the decline in $\mathrm{D}_{\mathrm{ewc}}$ (Bunting, 1976; B. A. ten Hag, 1976, personal communication; Wilkinson \& Osbourn, 1975). 


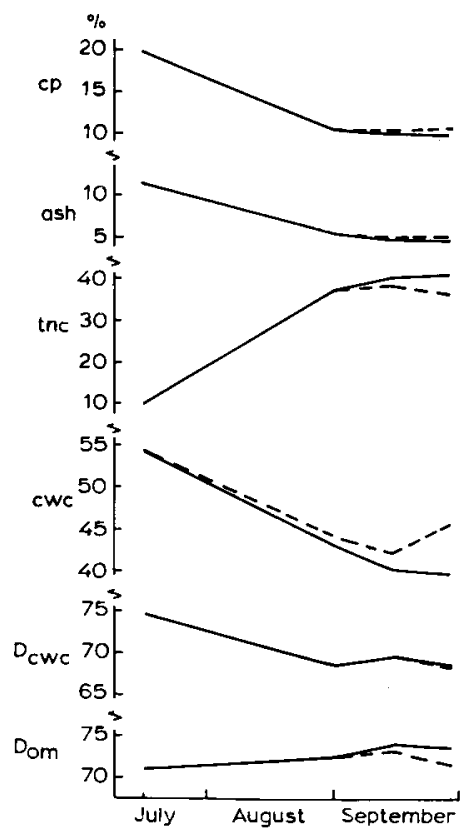

Fig. 2 Chemical composition and digestibility of fertile ( - ) and sterile (-....) maize. Average of three hybrids.

However in the sterile crop the smaller production of carbohydrate in September resulted in a steady content of crude protein and ash, and some increase in cwc. $D_{\text {cwc }}$ did not differ between sterile and fertile maize. As the smaller carbohydrate production did not compensate for the decline in $D_{\text {cwe }}, D_{o m}$ finally declined with age in the sterile plants.

\section{Discussion}

The results presented help to answer the three problems.

\section{Production pattern of maize}

Maize originates from a subtropical climate in which it can grow rapidly from seed emergence to a tall plant about $4 \mathrm{~m}$ high with much leaf area. Consequently optimum plant density is about 5-6 $\mathrm{m}^{-2}$ (Allison \& Eddowes, 1968). After flowering and ceasing vegetative growth, grain filling is initiated. This occurs rapidly in the bright and warm climate, and almost completely from photosynthesis, as the stover weight hardly alters during that period (Allison \& Watson, 1966; Krishnamurthy et al., 1972). However if conditions for photosynthesis are less favourable, as with high plant density, low light intensity, defoliation, and decreased photosynthetic capacity of the leaves, then grain filling proceeds faster than photosynthesis and the stover loses weight (Allison, 1969; Allison \& Watson, 1966; Goldsworthy, 1974). The same happens if leaves lose their photosynthetic capability by senescence or adverse conditions (H. van Arkel in Kenya, 1976, personal communication). 
However, in a temperate climate, maize grows much slower, plants remain shorter $(2-2.5 \mathrm{~m})$, as in the present trial and leaf area is less. Optimum plant density is therefore greater $\left(9-10 \mathrm{~m}^{-2}\right.$, Allison \& Eddowes, 1968). Grain filling occurs at the end of the summer and in autumn, with low light intensity and low temperature. So photosynthesis and crop growth rate are low, but rate of grain filling at $100-150 \mathrm{~kg} \mathrm{ha}^{-1} \mathrm{~d}^{-1}$ is only a little less than in the subtropics (Goldworthy, 1974; Hanway \& Russell, 1969). Yet grain yield is generally not less than in the tropics and subtropics (Milbourne, 1976), possibly because of the longer period of grain filling and the delay in ripening.

\section{Dry-matter distribution}

As rate of grain filling in temperate regions is somewhat less than in warmer and brighter areas with the higher growth rate, grain filling must be partly at the expense of solubles accumulated in the stover. Even with the bright and warm August and September of 1975, growth rate lagged somewhat behind grain filling rate. With a grain production of $3500 \mathrm{~kg} \mathrm{ha}^{-1}$ in September the stover contributed only about $1000 \mathrm{~kg} \mathrm{ha}^{-1}$ to it in the fertile maize. However average contribution of the stover to the grain in the Netherlands was about $2500 \mathrm{~kg} \mathrm{ha}^{-1}$ in the years 1970-1974 (B. A. ten Hag, 1976, personal communication), and resulted in a low content of wsc of the stover.

Similar contributions from the stem were reported by Adelana \& Milbourne (1972) and Bunting (1976) from Britain. This is not much more than in the somewhat better climate of the Virginian mountains (about $2000 \mathrm{~kg} \mathrm{ha-1}$, Bryant et al., 1966) and of upstate New York (about $1600 \mathrm{~kg} \mathrm{ha}^{-1}$, Hoyt \& Bradfield, 1962). In the bad autumn of 1974 in the Netherlands, stover contribution was still over $3000 \mathrm{~kg} \mathrm{ha}^{-1}$, when grain production almost completely occurred at the expense of the stover.

In tropical regions, stalk contribution to the grain is generally less than $1000 \mathrm{~kg}$ ha $^{-1}$ (Allison, 1971; Allison \& Watson, 1966).

Probably grain production in temperate regions is mainly source-dependent, whereas it is sink-dependent in the tropical and subtropical regions (Bunting, 1975; Goldsworthy, 1974). However grain production can also become source dependent in tropical regions with high plant density and low light intensity.

These phenomena are not only evident in maize but also in other grains. Thus Spiertz (1974) found in favourable conditions for grain filling in wheat (high temperature) that rate of grain filling exceeded crop growth rate, so wsc was extracted from the straw, whereas at low temperature straw yield remained almost constant or even increased somewhat (J. Vos, 1976, personal communication).

So if conditions are more favourable for grain filling than for crop growth, dry matter will be translocated from the stover or straw to the grain. If grain filling is less than growth rate, then the stover accumulates dry matter.

\section{Yield losses in sterile maize}

The sterile treatments in the present trial were an extreme case of unfavourable conditions for grain production. Here the stover yield increased considerably during 
grain filling. All plant parts increased in weight, but the solid stem and husks + shanks most. However whole crop production of the sterile plants lagged behind that of the fertile crop, the discrepancy being $0,7.2$ and $14.4 \%$ on 1,15 and 29 September, respectively. Discrepancies might have been less if the weather had not been so bright and warm.

These differences in yield were greater than those of Bunting $(1975 ; 1976)$ in the temperate climate of England who mentions discrepancies of $6-7 \%$ at densities of 7-10 $\mathrm{m}^{-2}$. At higher densities, he found smaller and at lower densities greater differences. This suggests that there are limits to the accumulation capacity of the stover for assimilates. This is still more evident in the data of King et al. (1972), who found that yield of sterile plants lagged behind the fertile plants by about $15 \%$ in the bright and warm conditions of Alabama at 3 plants per $\mathbf{m}^{2}$. Similar great differences are reported in open stands by Kiesselbach (1948) in Nebraska (27\%) and Campbell (1964) in Missisippi (18-36\%), and may also be inferred from Moss (1962) in Connecticut. Comparison of their results in the United States with Bunting's $(1975,1976)$ and ours suggests that, in north-west Europe with the higher plant densities and cloudier and cooler climate, grain formation is less essential for dry matter production than in warmer and brighter regions with opener stands.

However in silage maize, yield of digestible organic matter is more important than yield of dry matter. As the yield difference between sterile and fertile maize mainly consisted of highly digestible carbohydrate, yield losses in digestible organic matter were greater $(0,8.2$ and $17.0 \%$ on 1,15 and 29 September, respectively) than of dry matter. As the yield differences in the brighter autumns of the United States would also consist of non-structural carbohydrate, yield discrepancies of digestible organic matter would be much greater than those of dry matter mentioned above. In contrast, if the maximum of thc in the stover may not be reached discrepancies may be zero, as on 1 September 1975 or very small like the bad autumn of 1974 (Bunting, 1975, 1976).

Dry-matter content of the forage at harvest should be above $25 \%$ to prevent great silage losses. As the sterile plants remain wetter during the final phase of grain filling, there is a greater risk that sterile maize does not reach $25 \%$ dry matter at harvest, especially in a bad autumn. Moreover, as the soluble carbohydrate is fermented rapidly in the silage and starch is hardly fermented (McAllan \& Phipps, 1977) slightly greater losses may be expected from the sterile plants than from the fertile. Consequently differences in yield of digestible organic matter of sterile maize after ensiling could be even greater than of harvested digestible organic matter.

These losses occur when grain filling is completely prevented, but one may assume that they are proportional to the extent of grain filling. So at the high plant densities and in the cool autumn of temperate regions, grain filling is necessary but less essential than in the tropics and subtropics.

\section{Some practical implications}

The results seem relevant to farming practice when seed setting is incomplete for 
some reason, but they appear important also in plant breeding.

Plant breeders in the temperate regions, following their colleagues in the tropics and subtropics, aimed at a high grain production and a high grain proportion in maize for silage. However, in varietal tests in the Netherlands H. Vos (1975, personal communication) found a positive correlation between content of ear and of crude fibre of the stover. This suggests that cultivars with a high ear content have a poor digestibility of the stover and apparently better extract the soluble substances from it, as did Capella in our experiment. Berthet \& Gallais (1975) found the same and it can also be inferred from Campbell's work (1964). Consequently cultivars with a high grain content may be overvalued if that is the sole criterion in silage maize breeding. Stover yield and quality is a worthwhile criterion too. So preliminary data from a co-operative research project in 1977 of the Government Institute for research on varieties of cultivated plants at Wageningen and our Department (to be published) show that ear content explained about a quarter of the genotypic variation in $\mathrm{D}_{o m}$ in the whole crop, but $\mathrm{D}_{\text {ewc }}$ from the stover explained even $60 \%$ of the variation. So even in the cool temperate regions where a maize crop of high digestibility is grown, breeding for a high stover digestibility seems important. This is probably even more important for hotter climates.

So perhaps grain content is more essential for yield and nutritive value of maize for silage if production of wsc (photosynthesis) proceeds uninhibited for longer. However grain filling becomes less essential with a smaller production of wsc and a greater exhaustion of the stover. A high grain content is even undesirable if so much carbohydrate is exhausted that harvest losses become greater because of stalk rot (Campbell, 1964).

Still another aspect seems important, especially for the tropics. Former research (Deinum, 1976) has shown that a high temperature is detrimental to digestibility of cell walls in leaf and stem of maize, because of heavy lignification. This implies that in hot regions the cell walls of the stover are poorly digestible. So it is fortunate that tropical maize combines grain filling with accumulation of tnc in the stover, as the stover hardly loses weight. If not, silage quality might be even poorer. This great effect of temperature on lignification is possibly less pronounced in hybrids with the brown-midrib gene as they are less lignified and more digestible. So this gene may be of much greater benefit in the hot tropics and subtropics than in cool temperate regions, in which $\mathrm{D}_{\mathrm{cwc}}$ is already rather high. So breeding for a good stover quality seems promising in cool climates; it is mandatory for a good silage quality in hotter regions.

\section{Acknowledgments}

We thank Mr A. Hol and Mr W. Neervoort for their share in handling the trial, collecting the data and summarizing the information and Mrs C. de Wit and Mrs E. Zantman for the involved and precise chemical analysis. 


\section{References}

Adelana, B. O. \& G. M. Milbourne, 1972. The growth of maize. II. Dry-matter partitioning in three maize hybrids. J. agric. Sci., Camb. 78: 73-78.

Allison, J. C. S., 1969. Effect of plant population on the production and distribution of dry matter in maize. Ann. appl. Biol. 63: 135-144.

Allison, J. C. S., 1971. Analysis of growth and yield of inbred and crossbred maize. Ann. appl. Biol. 68: 81-92.

Allison, J. C. S. \& M. Eddowes, 1968. Climate and optimum plant density in maize. Nature 220: $1343-1344$.

Allison, J. C. S. \& D. J. Watson, 1966. The production and distribution of dry matter in maize after flowering. Ann. Bot. 30: 365-381.

Allison, J. C. S. \& H. Weinmann, 1970. Effect of absence of developing grain on carbohydrate content and senescence of maize leaves. Pl. Physiol. 46: 435-436.

Becker, W. R. \& G. H. de Haan, 1955. Een proef met verschillende oogsttijden van snijmais. Verslag CILO: 170-176.

Berthet, M. \& A. Gallais, 1975. Essais de definition d'un mais fourrage. Fourrages 62: 26-30.

Bryant, H. T., R. E. Blaser, R. C. Hammes Jr. \& J. T. Huber, 1966. Evaluation of corn silage harvested at two stages of maturity. Agron. J. 55: 253-255.

Bunting, E. S., 1975. The question of grain content and forage quality in maize: comparison between isogenic fertile and sterile plants. J. agric. Sci., Camb. 85: 455-463.

Bunting, E. S., 1976. Effects of grain formation on dry matter distribution and forage quality in maize. Expl Agric. 12: 417-428.

Campbell, C. M., 1964. Influence of seed formation of corn on accumulation of vegetative dry matter and stalk strength. Crop Sci. 4: 31-35.

Daynard, T. B., J. W. Tanner \& D. J. Hume, 1969. Contribution of stalk soluble carbohydrate to grain yield. Crop Sci. 9: 831-834.

Deinum, B., 1976. Efect of age, leaf number and temperature on cell wall and digestibility of maize. In: Carbohydrate research in plants and animals. Miscellaneous Papers, Agricultural University, Wageningen, No 12: 29-41.

Deinum, B. \& J. G. P. Dirven, 1971. Climate, nitrogen and grass. 4. The influence of age on chemical composition and in vitro digestibility of maize (Zea mays L.) and tall fescue (Festuca arundinacea Schreb.). Neth. J. agric. Sci. 19: 264-272.

Goldsworthy, P., 1974. Maize physiology. Proc. World-wide maize improvement in the 70's and the role of CIMMYT. EI Batan, Mexico, 9-1-936.

Hanway, J. J. \& W. A. Russell, 1969. Dry matter accumulation in corn (Zea mays L.) plants: comparison among single-cross hybrids. Agron. J. 61: 947-951.

Hoyt, P. \& R. Bradfield, 1962. Effect of varying leaf area by partial defoliation and plant density on dry-matter production in corn. Agron. J. 54: 523-525.

Kiesselbach, T. A., 1948. Endosperm type as a physiological factor in corn yields. $J . A m$. Soc. Agron. 40: 216-236.

King, C. C., D. L. Tompson \& J. C. Burns, 1972. Plant component yield and cell contents of an adapted and a tropical corn, Zea mays L. Crop Sci. 12: 446-449.

Krishnamurthy, K., A. Bommegowda, N. Venugopal, M. K. Jagamath, G. Raghunatha \& B. G. Rajashekara, 1971. Pattern of dry-matter accumulation and distribution in maize (Zea mays L.) Indian J. Agron. 17: 104-109.

McAllan, A. B. \& R. H. Phipps, 1977. The effect of sample date and plant density on the carbohydrate content of forage maize and the changes that occur on ensiling. J. agric. Sci., Camb. 89: 589-597.

Milbourne, G. M., 1976. Yield potential of maize in different regions of the world. Ann. appl. Biol. 87: 242-245.

Moss, D. N., 1962. Photosynthesis and barrenness. Crop Sci. 2: 366-367.

Palmer, A. F. E., G. H. Heichel \& R. B. Musgrave, 1973. Patterns of translocation, respiratory loss and redistribution of ${ }^{14} \mathrm{C}$ in maize labeled after flowering. Crop. Sci. 13: 371-376. 


\section{B. DEINUM AND J. KNOPPERS}

Spietz, J. H. J., 1974. Grain growth and distribution of dry matter in the wheat plant as influenced by temperature, light intensity and ear size. Neth. J. agric. Sci. 22: 207-220.

Van Soest, P. J., 1977. Modified procedure for determining plant cell wall by the neutral detergent procedure. Paper presented at the Annual Meeting of the American Society of Animal Science.

Van Soest, P. J., R. H. Wine \& L. A. Moore, 1966. Estimation of the true digestibility of forages by the in vitro digestion of cell walls. Proc. 10th int. Grassl Congr. (Helsinki) 438-441.

Wilkinson, J. M. \& D. F. Osbourn, 1975. Objectives in breeding forage maize for improved nutritive value. Proc. 8th Congr. Eucarpia (Versailles). 